\title{
A Preliminary Study on the Impact of UCK2 Knockdown in DLD-1 Colorectal Cells Treated with DHODH Inhibitor
}

(Kajian Awal ke atas Kesan Penyahfungsian UCK2 di dalam Sel Kolorektum DLD-1 yang Dirawat dengan Perencat DHODH)

\author{
Mohamad Fairus Abdul Kadir, Puteri Shafinaz Abdul-Rahman, KaVitha Nellore \& Shatrah \\ OTHMAN*
}

\begin{abstract}
Brequinar sodium (BQR) is a well-studied inhibitor of the dihydroorotate dehydrogenase (DHODH) enzyme. Both the DHODH and uridine-cytidine kinase 2 (UCK2) enzymes have been reported to be over-expressed in cancer cells to maintain the cells high demand for DNA and RNA for their proliferation. In this study, we aim to further sensitize cells to the effects of BQR by knocking down the UCK2 activity. In DLD-1 UCK2 knockdown cells, no change in the sensitivity of cells to $B Q R$ was observed. Uridine is known to reverse the anti-proliferative effect of DHODH inhibitors via the salvage pathway. We observed abrogation of approximately $30 \%$ of the uridine reversal effect in UCK 2 knockdown cells compared to the wild type cells. Our finding indicates that the loss of UCK2 activity in the salvage pathway did not enhance the BQR-mediated cell proliferation inhibition but it abrogates the uridine reversal in the cells.
\end{abstract}

Keywords: BQR; DHODH; TAS-106; UCK2; uridine abrogation

\section{ABSTRAK}

Natrium Brequinar (BQR) dikenali sebagai salah satu perencat enzim dihidroorotat dehidrogenase (DHODH). Keduadua enzim DHODH dan uridina-sitidina kinase 2 (UCK2) diekspreskan secara berlebihan di dalam sel kanser untuk mengekalkan permintaan tinggi ke atas DNA dan RNA bagi pembahagian sel. Kajian ini bertujuan untuk memekakan sel kanser terhadap BQR dengan menurunkan aktiviti UCK2. Dalam sel rebah UCK2 DLD-1, tiada sebarang perubahan kesensitifan sel terhadap BQR diperhatikan. Uridina telah diketahui dapat membalikkan kesan anti-pembahagian perencat DHODH melalui tapak jalan penyelamatan pirimida. Kami mendapati bahawa pembatalan kesan pembalikan uridina adalah lebih kurang 30\% di dalam sel rebah UCK2 berbanding sel jenis liar. Penemuan kami menunjukkan bahawa kehilangan aktiviti UCK2 di dalam laluan penghematan tidak meningkatkan perencatan pembahagian sel berperantarakan BQR tetapi membatalkan pembalikan uridina di dalam sel.

Kata kunci: BQR; DHODH; pembatalan uridina; TAS-106; UCK2

\section{INTRODUCTION}

Pyrimidine bases whose derivatives include cytosine, uracil, and thymine are synthesized via de novo and salvage pathways of the cells. Dihydroorotate dehydrogenase (DHODH) and uridine-cytidine kinase 2
(UCK2) are enzymes that involved in the de novo and salvage processes, respectively. Fast growing cancer cells acquire a high amount of pyrimidine to sustain their growth requirement by exploiting the de novo pyrimidine biosynthesis (Balague et al. 2012). In the de novo pathway, 
six enzymes are involved in the synthesis of pyrimidine. All other enzymes of pyrimidine biosynthesis, except DHODH are cytosolic. The first reaction is conducted by the glutamine (Gln) to form carbamyl phosphatase (CAP) followed by steps catalyzed by three separate enzymes (Asp transcarbamoylase, dihydroorotase and dihydroorotate dehydrogenase). The fifth and sixth steps are catalyzed by a single, bifunctional enzyme (UMP synthase) forming the first true pyrimidine ribonucleotide (UMP) (Schröder et al. 2005). In this pathway, DHODH is the fourth sequential enzyme with a rate-limiting step behaviour in the mitochondria that catalyzes the conversion of dihydroorotate (DHO) to orotate (ORO) (Baumgartner et al. 2006; Gattermann et al. 2004).

DHODH has been studied as a drug target for application such as in cancer therapy, transplant rejection, rheumatoid arthritis (RA), psoriasis, and autoimmune diseases (Breedveld \& Dayer 2000; Lolli et al. 2018). Leflunomide and its metabolite, A771726 (LFM), 4SC-101, brequinar sodium (BQR), DD264, DSM 265, redoxal and A3 (Hoffmann et al. 2011; Lolli et al. 2018; Ortiz-Riaño et al. 2014) are among the reported inhibitors for targeting DHODH. BQR has shown a promising preclinical antitumor activity against a number of human cancer xenograft but was withdrawn in Phase II studies as it showed toxicity and no effect against solid tumors were seen due to insufficient DHODH inhibition. However, recent studies with BQR showed that the toxicity effects of this drug can be overcome via scheduled administration which appears to have clinical benefits (Lolli et al. 2018; Sykes et al. 2016). Also, we have recently reported on the effect of $\mathrm{BQR}$ on breast cancer cells which showed that the treatment with $B Q R$ exhibited highest potency in cancer cells compared to normal cells (Fairus et al. 2017).

Conversely, in the salvage pathway, UCK enzyme phosphorylate free uracil base into uridine monophosphate (UMP) and a final product of uridine triphosphate (UTP) is obtained (Katahira \& Ashihara 2002). The nucleosides cytidine and deoxycytidine can be salvaged along the uracil pathway by cytidine deaminase, which converts them to uridine and deoxyuridine, respectively. Between the two pyrimidine bases, only uracil seems to play roles in salvaging nucleotide synthesis without the evidence of cytosine phosphoribosyltransferase activity found in any organisms (Katahira \& Ashihara 2002). Nucleoside analogues (NA) which mimic physiological nucleosides constitute an important class of antimetabolites used in the treatment of cancers via the activation by kinases and the formation of the active triphosphates metabolites (Galmarini et al. 2001). TAS-106 is among the NA that has been investigated for potential use as a chemotherapeutic agent for the treatment of cancer (Murata et al. 2004). In in vitro assays, TAS-106 rapidly undergo phosphorylation to a 5'-triphosphate by UCK enzyme after its uptake into cells, that subsequently inhibits RNA polymerases activity and perturbs RNA synthesis (Matsuda \& Sasaki 2004; Shimamoto et al. 2002b). UCK2 are also known to activate some pharmacological ribonucleoside analogues such as 3'-ethynyl nucleosides (Abdelrahim et al. 2013; Kazuno et al. 2007; Matsuda et al. 1999; Naito et al. 2002). Hence, loss of $U C K 2$ activity may lead to resistance to TAS-106 (Shimamoto et al. 2002a).

Considering that DHODH is an important enzyme required for pyrimidine de novo biosynthesis and shuttles reducing equivalents to the mitochondrial respiratory chain, we hypothesized that DHODH inhibitor may also show specific cytotoxicity when the substrate for pyrimidine salvage pathway are limiting (Figure 1). Additionally, inhibitor of DHODH such as LFM and BQR which have shown several in vitro efficacies has not been able to be translated in vivo, doubtless due to the ability of the body to preserve a relentless supply of uridine via the cellular salvage of pyrimidine nucleotides (Okesli et al. 2017; Okesli-Armlovich et al. 2019; Wang et al. 2011). Thus, in this study, we examined the effect of UCK2 knockdown in cancer cells with the hypothesis that it would sensitize the cells further to treatment with a DHODH inhibitor known as BQR.

\section{MATERIALS AND METHODS}

\section{CHEMICALS AND CELL LINES}

TAS-106, BQR and 4SC-101 were synthesized by Aurigene Discovery Technologies Ltd. Bangalore, India. DLD-1 (human colon carcinoma), HT-1080 (human fibrosarcoma) and HEK-293 (transformed normal kidney) cells were procured from American Type Cell Culture, ATCC (USA). AZ-521 (human duodenal carcinoma) and NUGC-3 (human gastric adenocarcinoma) cell line was procured from Japanese Cell Culture Bank, JP. DLD1 and NUGC-3 cells were maintained in RPMI-1640 medium (Sigma, USA). AZ-521, HT-1080 and HEK-293 were cultured in Dulbecco's modified Eagle's medium (Sigma, USA). All media were supplemented with 10\% heat-inactivated FBS (Sigma, USA) and 1X Pen-strep (Gibco, USA). Monoclonal primary antibody against 


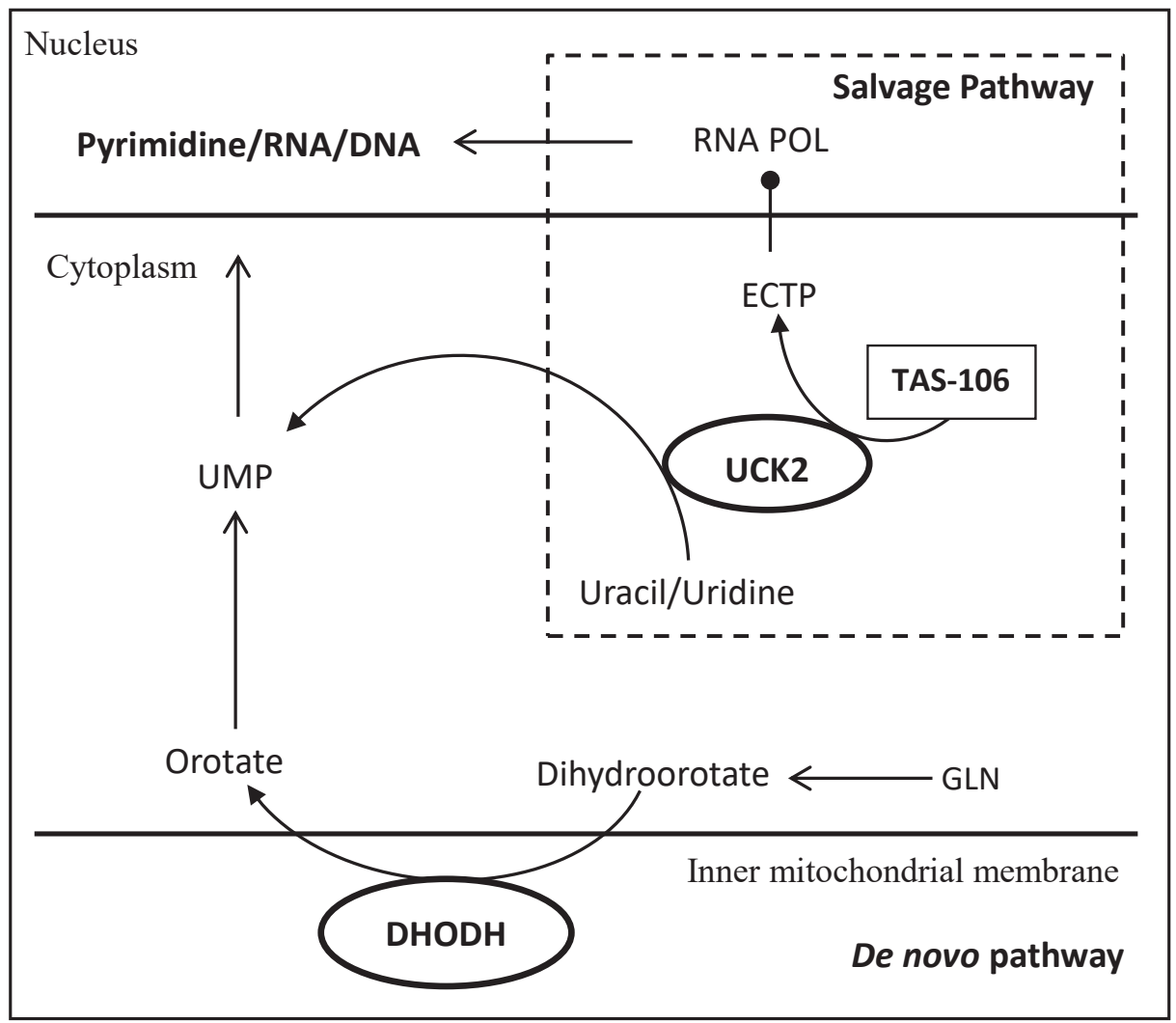

FIGURE 1. De novo and salvage pathway for pyrimidine biosynthesis. In the de novo pyrimidine synthesis, glutamine is converted into dihydroorotate in the outer membrane of the mitochondria before entering inner membrane of mitochondria. In the inner membrane of the mitochondria, the DHODH enzyme acts on the dihydroorotate and converts it into orotate back in to the outer membrane of the mitochondria. Here, the orotate will finally convert to uridine monophosphate (UMP) before entering the pyrimidine pool. In the salvage pathway, the UCK 2 enzyme acts on uracil/uridine and converts it to UMP. Additionally, in treatment with TAS-106, UCK2 helps to phosphorylate TAS-106 converting it to ECTP which eventually inhibits the RNA polymerase (RNA POL). UMP is the common end product of these two pathways

human UCK2 was purchased from ProteinTech, USA and $\beta$-actin antibody was procured from SignalChem, Canada. Secondary antibody, anti-rabbit polyclonal antibody and Uridine were secured from Sigma, USA. The siUCK2 and its negative control were purchased from Qiagen Biotechnology, USA.

\section{CELL GROWTH INHIBITION ASSAY BY XTT}

Three cell lines were investigated for their sensitivity to treatment with TAS-106, BQR, and 4SC-101. Cells were seeded in 96-well plates and allowed to grow to a confluency of $70-85 \%$. For uridine rescue experiment, cells treated with variable concentrations of inhibitors $(0.015 \mu \mathrm{M}-100 \mu \mathrm{M})$ were co-administered with uridine. After $72 \mathrm{~h}$ of treatment, $100 \mu \mathrm{L}$ of $1 \mathrm{mg} / \mathrm{mL}$ XTT (Sigma, USA) together with $25 \mu \mathrm{M}$ of phenyl methylsulfonate; PMS (Sigma, USA) was added into each well. The absorbance at $450 \mathrm{~nm}\left(\mathrm{OD}_{450}\right)$ was taken after $2-4 \mathrm{~h}$ using Victor X5 multi plate reader (Perkin Elmer, USA). The percentage inhibition was calculated by comparing the absorbance $\mathrm{OD}_{450}$ of inhibitor-treated wells with the DMSO control wells as mentioned in (1). $\mathrm{EC}_{50}$ was determined using GraphPad Prism 6. 
RNAI KNOCKDOWN OF THE UCK2 GENE IN DLD-1, HEK293 AND AZ-521 CELLS

Transfections were performed using the siUCK2 gene as follows: 5'-CCGGATGCCTTTGACAATGAA-3' (Hs UCK2_5) and 5'-TCAGTACATTACGTTCGTCAA-3' (Hs UCK2 $_{6}$ ), and the All Stars as the negative control (NC) siRNA. Generally, confluent cells were harvested and seeded into 6-well plates at a density of $1.5 \times 10^{5}$ cells/well. After $24 \mathrm{~h}$, equal concentrations of siUCK2 and $\mathrm{NC}$ were prepared in Opti-MEM and were incubated at room temperature (RT) for $30 \mathrm{~min}$ together with Lipofectamine 2000 (Invitrogen, USA). The preincubated mixture was added drop-wise into each well and further incubated for $5 \mathrm{~h}$ at $37{ }^{\circ} \mathrm{C} / 5 \% \mathrm{CO}_{2}$. Subsequently, the media was replaced with fresh complete media and the incubation was continued for a further $48 \mathrm{~h}$ for gene knockdown.

\section{PREPARATION OF CELL LYSATES}

The transfected and non-transfected cells were harvested by trypsinizing the cells with $1 \mathrm{X}$ trypsin EDTA (Sigma, USA) after $48 \mathrm{~h}$ of incubation. The harvested cells were washed twice with $1 \mathrm{X}$ cold PBS and mixed with appropriate amount of RIPA buffer (Sigma, USA) containing protease and phosphatase inhibitor cocktails (Sigma, USA). The cells were placed on ice for $10 \mathrm{~min}$ and centrifuged at $15000 \times \mathrm{g}$ at $4{ }^{\circ} \mathrm{C}$ for $15 \mathrm{~min}$. The supernatant was collected and stored at $-80^{\circ} \mathrm{C}$ for future analysis.

\section{SDS-PAGE AND WESTERN BLOTTING}

Cell lysates were thawed and their protein content was determined using Pierce BCA Protein Assay Kit (Thermo Scientific, USA). Equal amounts of protein were loaded into to a $12 \%(\mathrm{w} / \mathrm{v})$ acrylamide gel. After electrophoresis, the proteins were transferred onto a PVDF membrane (GE Healthcare, USA) by semi-dry transfer for $30 \mathrm{~min}$ and blocked for one hour with 5\% skimmed milk (Cell Signalling Technology, USA) in Tris buffer saline with Tween-20 (TBST). The membrane was incubated with anti-UCK2 (1:1000) and anti- $\beta$-actin $(1: 1000)$ overnight at $4{ }^{\circ} \mathrm{C}$. After washing with TBST, the membrane was incubated with anti-rabbit polyclonal antibody $(1: 15000)$ for $2 \mathrm{~h}$. After being probed with HRP-conjugated secondary antibodies, bound antibodies were detected with electro-chemiluminescent (ECL) Western blotting detection system (Pierce, USA).

\section{STATISTICAL ANALYSIS}

Experiments were repeated three times and mean \pm SEM was determined. To calculate experimental $p$ values, a two-sided Student $t$-test and ANOVA analysis was applied where necessary for comparison of continuous variables between two groups. Differences were considered significant when the $p$ values were $<0.05,0.01,0.001$ or 0.0001 . Effective concentration at $50 \%\left(\mathrm{EC}_{50}\right)$ was determined using GraphPad Prism 7.0 nonlinear regression, sigmoidal curve best fit model.

\section{RESULTS}

\section{SENSITIVITY OF CELLS TO TAS-106, BQR AND 4SC-101}

Chemo-sensitivity to TAS-106 was determined in five cell lines i.e. HT-1080, AZ-521, DLD-1, HEK-293 and NUGC3 cells (Figure 2). These cell lines were chosen based on earlier studies where these cells showed significant sensitivity to TAS-106 (Murata et al. 2004; Shimamoto et al. 2002b). On the other hand, we also tested other NA like 5-Azacytidine (5-Aza) and 3'-ethynyluridine (EUrd) to compare their sensitivity in some selected cells line (data not shown). Based on that preliminary study, TAS-106 has demonstrated the best activity in nanomolar range. Our findings showed that all 5 cell lines showed sensitivity to TAS-106 ranging from 10-200 nM. All cell lines except NUGC-3 cells showed EC50 lower than $100 \mathrm{nM}$ (Table 1). All the cell lines were sensitive to TAS-106 with HEK-293 being the most sensitive to this inhibition. The sensitivity of DLD-1, HT-1080 and AZ521 were similar to previous findings (Shimamoto et al. 2002b). Additionally, we have tested two known DHODH inhibitors i.e. $\mathrm{BQR}$ and $4 \mathrm{SC}-101$ on the entire abovementioned cell lines (Table 1). HT-1080 and NUGC-3 cells exhibited the least sensitivity to both the inhibitors with lower than $50 \%$ at $30 / 100 \mu \mathrm{M}$ concentration of both the inhibitors. In addition, the rest of the cells showed greater sensitivity to $\mathrm{BQR}$ ranging from $70-150 \mathrm{nM}$. The inhibitions with $\mathrm{BQR}$ on these cells are significantly lower compared to 4SC-101 which showed inhibition more than $3 \mu \mathrm{M}$ (Table $1 \&$ Figure 3 ). Hence, these cells which $\mathrm{EC}_{50}$ could be determined when screened against DHODH inhibitors namely DLD-1, HEK-293 and AZ-521 (Figure 3) were chosen for further assays.

\section{KNOCKDOWN OF UCK2 WITH SIRNA AND ITS IMPACT ON SENSITIVITY TO TAS-106}

Following transfection with siUCK2 in the knockdown assay, the expression levels of UCK2 in DLD-1 and HEK293 were markedly decreased, but no significant change was observed in AZ-521 cells (Figure 4). Correspondingly, as shown in Table 1, the highest fold increase in TAS-106 $\mathrm{EC}_{50}$ due to UCK2 knockdown was observed in HEK293 and DLD-1 cells ( 20 -fold) whereas AZ-521 cells 
demonstrated only 4.5-fold increase. AZ-521 cells showed relatively high level of $U C K 2$ expression even after treatment with higher concentration of siRNA $(>50 \mathrm{nM})$ compared to the amount used for knockdown in DLD-1 and HEK-293 (10 nM). In addition, we also observed that at $96 \mathrm{~h}$ post transfections, UCK2 level in AZ-521 cells increased back to almost that of control cells (Figure 4). Similarly, in Figure 5, the DLD-1 and HEK-293 cells showed consistent suppression of UCK2 similar to that at $48 \mathrm{~h}$. With more than $90 \%$ of knockdown observed and effective TAS-106 resistance in DLD-1, further analysis was performed in these cells.
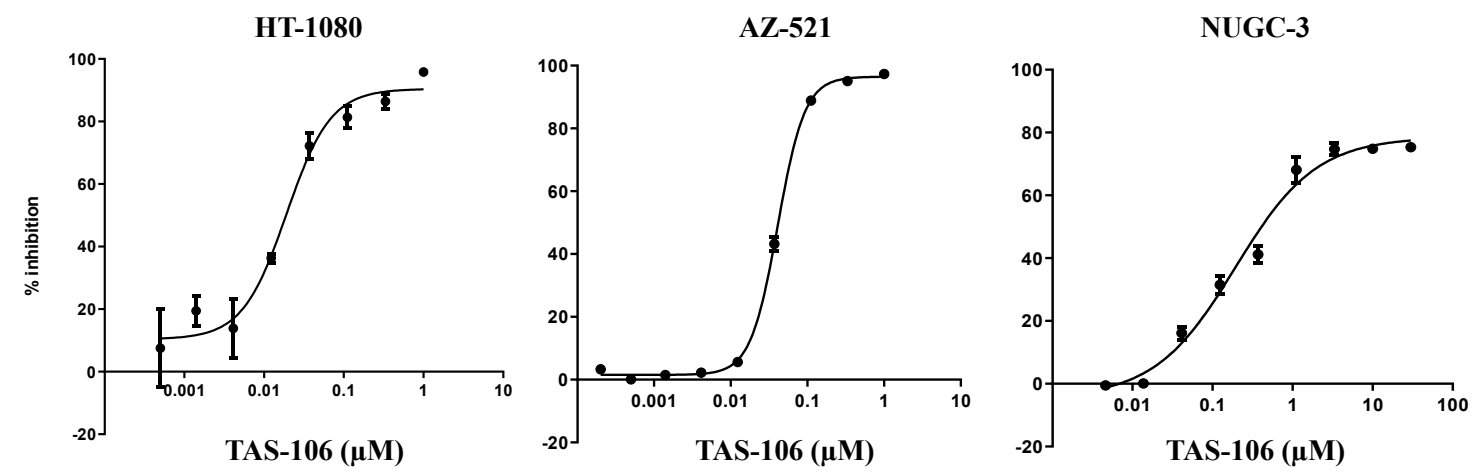

HEK-293
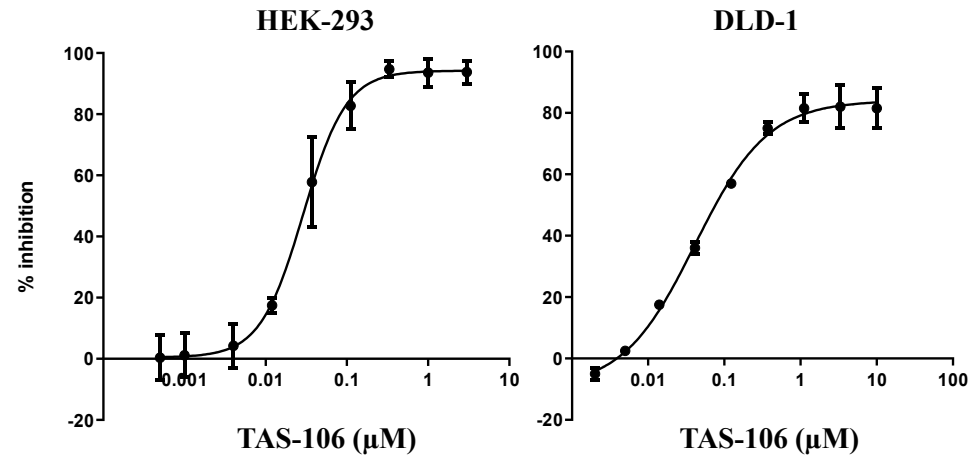

FIGURE 2. Inhibition of cell growths by TAS-106. HT-1080, AZ-521, NUGC-3, HEK-293 and DLD-1 cells were exposed continuously to the indicated concentrations of TAS-106 for $72 \mathrm{~h}$. Points are the mean \pm SD from three experiments

TABLE 1. Sensitivity of human normal and cancer cell lines to TAS-106, BQR and 4SC-101

\begin{tabular}{|c|c|c|c|c|c|c|}
\hline \multirow[b]{2}{*}{ Cell Line } & \multirow[b]{2}{*}{ Disease } & \multicolumn{4}{|c|}{ Sensitivity $\left(\mathrm{EC}_{50} \mu \mathrm{M}\right)$} & \multirow{2}{*}{$\begin{array}{l}\text { Relative } \\
\text { resistance } \\
\text { ratio * }\end{array}$} \\
\hline & & TAS-106 & $\mathrm{BQR}$ & 4SC-101 & $\begin{array}{l}\text { TAS- } 106 \text { treated } \\
\text { siUCK2 knocked } \\
\text { down cells }{ }^{\mathrm{b}}\end{array}$ & \\
\hline HEK-293** & $\begin{array}{l}\text { Transformed normal human } \\
\text { embryonic kidney cells }\end{array}$ & $0.016 \pm 0.004$ & $0.075 \pm 0.023$ & $8.218 \pm 1.154$ & $0.314 \pm 0.045$ & 19.6 \\
\hline AZ-521 & Duodenal adenocarcinoma & $0.040 \pm 0.002$ & $0.184 \pm 0.013$ & $3.942 \pm 0.599$ & $0.059 \pm 0.045$ & 1.5 \\
\hline DLD-1 & Colorectal cancer & $0.049 \pm 0.003$ & $0.106 \pm 0.043$ & $4.599 \pm 1.266$ & $1.084 \pm 0.058$ & 22.1 \\
\hline HT-1080 & Fibrosarcoma & $0.020 \pm 0.001$ & $>30$ & $>100$ & ND & ND \\
\hline NUGC-3 & Gastric adenocarcinoma & $0.223 \pm 0.055$ & $>100$ & $>100$ & ND & ND \\
\hline
\end{tabular}

*Relative resistance ratio $=\mathrm{b} / \mathrm{a}$ 

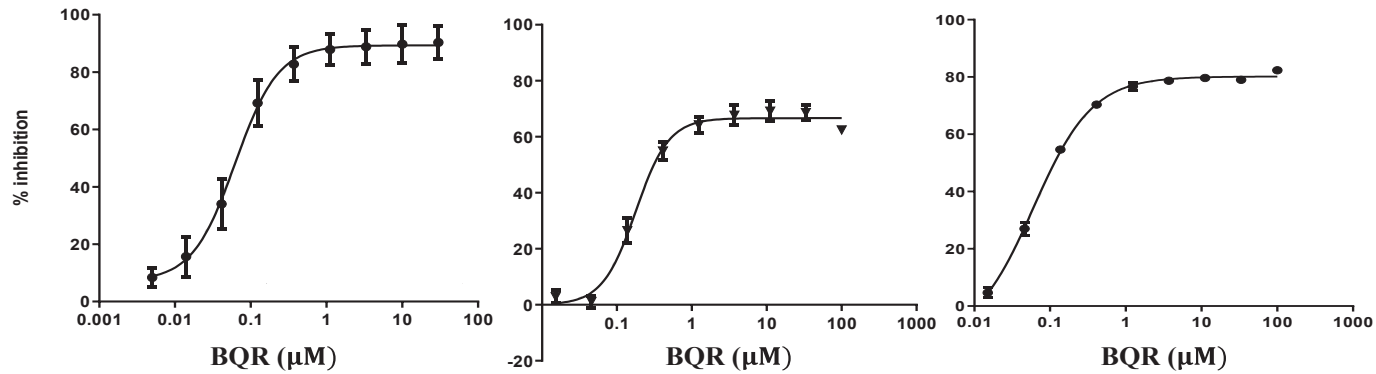

HEK293
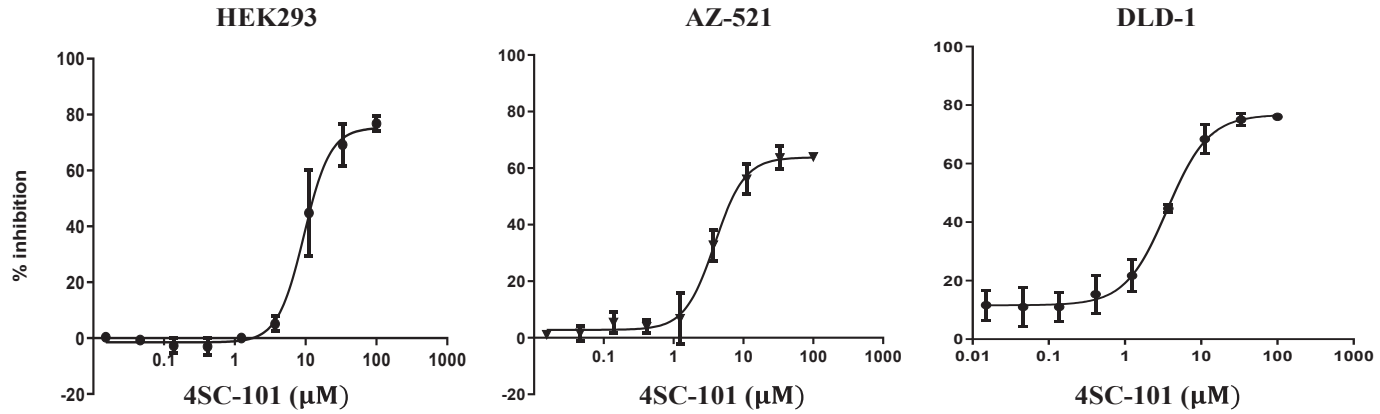

FIGURE 3. Inhibition of cell growths by BQR and 4SC-101. HEK-293, AZ-521 and DLD-1 cells were exposed continuously to the indicated concentrations of BQR and $4 \mathrm{SC}-101$ for $72 \mathrm{~h}$. Points are the mean $\pm \mathrm{SD}$ from three experiments

a)

DLD-1

AZ-521

HEK-293

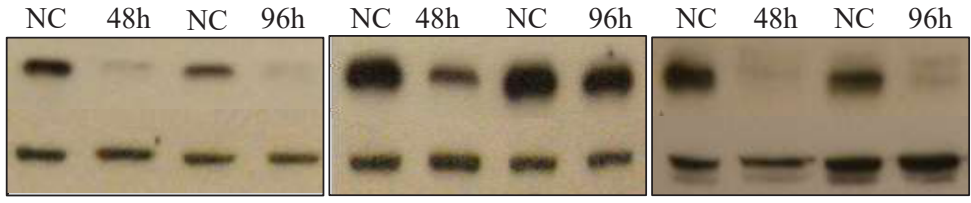

UCK2

$\beta$-actin

b)

UCK2 expression

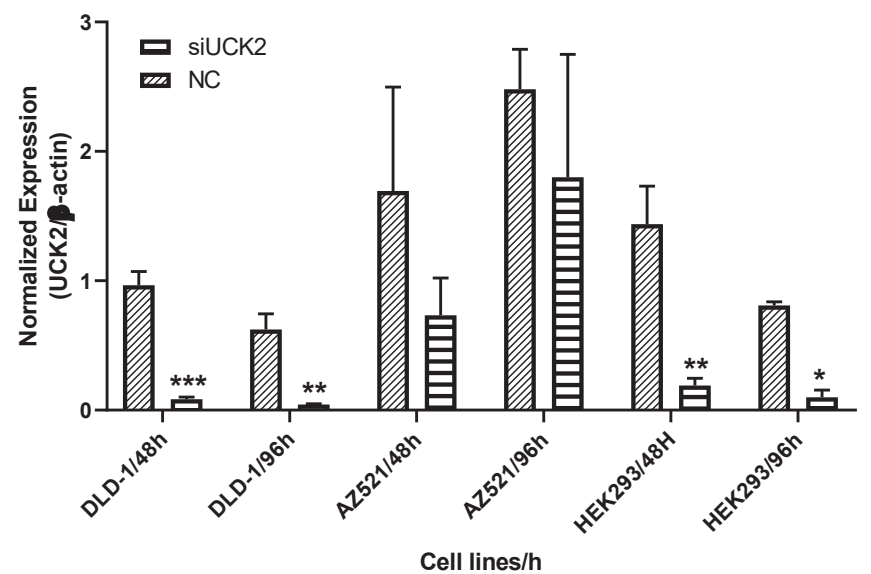

FIGURE 4. siUCK2 mediated knockdown in DLD-1, AZ521 and HEK293 cells a) Western blot analysis was performed on cells treated with $10 \mathrm{nM}$ siUCK2 for $48 \mathrm{~h}$ and $96 \mathrm{~h}$ post siRNA transfection,

b) The intensity of the bands was measure using Image Studio Lite ver 4. and represented as normalized expression of $U C K 2 / \beta$-actin. AllStar negative control (NC) was used at the same concentration of siUCK2 and was used to compare the efficiency of the knockdown in the cells. The significant difference between $\mathrm{NC}$ and siUCK2 cells for each time points were determined using two ways ANOVA. ${ }^{*} \mathrm{p}<0.05,{ }^{*} \mathrm{p}<0.01, * * * \mathrm{p}<0.001$ were achieved by comparing $\mathrm{NC}$ and $s i U C K 2$ of individual cell line on their respective time of harvest 
UCK2 KNOCKDOWN IN DLD-1 CELLS ABROGATED URIDINE REVERSAL FOR CELLS TREATED WITH BQR

To evaluate the role of the UCK2 gene on the cell proliferation inhibition by $\mathrm{BQR}$, the UCK2-knockdown DLD-1 cells were treated with uridine in combination with $\mathrm{BQR}$. The concentration of uridine used was 100 $\mu \mathrm{M}$ in the culture medium according to previous studies (Dorasamy et al. 2017; Sarkisjan et al. 2016). Prior to that, we have also tested the wild type DLD-1 cells treated with ranging concentrations of TAS-106 together with 100 $\mu \mathrm{M}$ of uridine (Urd) (Figure 5). In Table 2, we observed a 10 -fold shift in the in the $\mathrm{EC}_{50}$ of TAS-106 $(0.036 \mu \mathrm{M}$ to $0.330 \mu \mathrm{M}$ ) when uridine was supplemented. We also found that the UCK2-knockdown clearly reduced the sensitivity of cells to TAS-106 as seen in Table 1 (>21-fold). However, UCK2-knockdown did not further sensitize the cells to proliferation inhibition by BQR (Figure 6).
We assume that, when the effect of $U C K 2$ is lowered by knock down, the cells may not be able to continue to synthesis pyrimidine via the salvage pathway, hence, a shift in dose respond curve (DRC) of BQR was expected in $U C K 2$ knocked down cells. However, this was not seen in this study, suggested the low activity of UCK2 after the knockdown may still be sufficient for the cells to recover pyrimidine through the salvage pathway. On the other hand, the addition of uridine abrogated the uridine reversal in the knockdown cells by approximately $20-30 \%$ compared to the negative control. The cells showed dose-dependent rescue when supplemented with uridine together with BQR treatment. However, the uridine reversal abrogation was only noticeable at lower than $30 \mu \mathrm{M}$ BQR in DLD-1. Taken together, our data suggest that UCK2 knockdown reduces the capacity of $U C K 2$ enzyme in phosphorylating uridine and thus increasing the pyrimidine pool in the cells treated with BQR induced-DHODH inhibition.

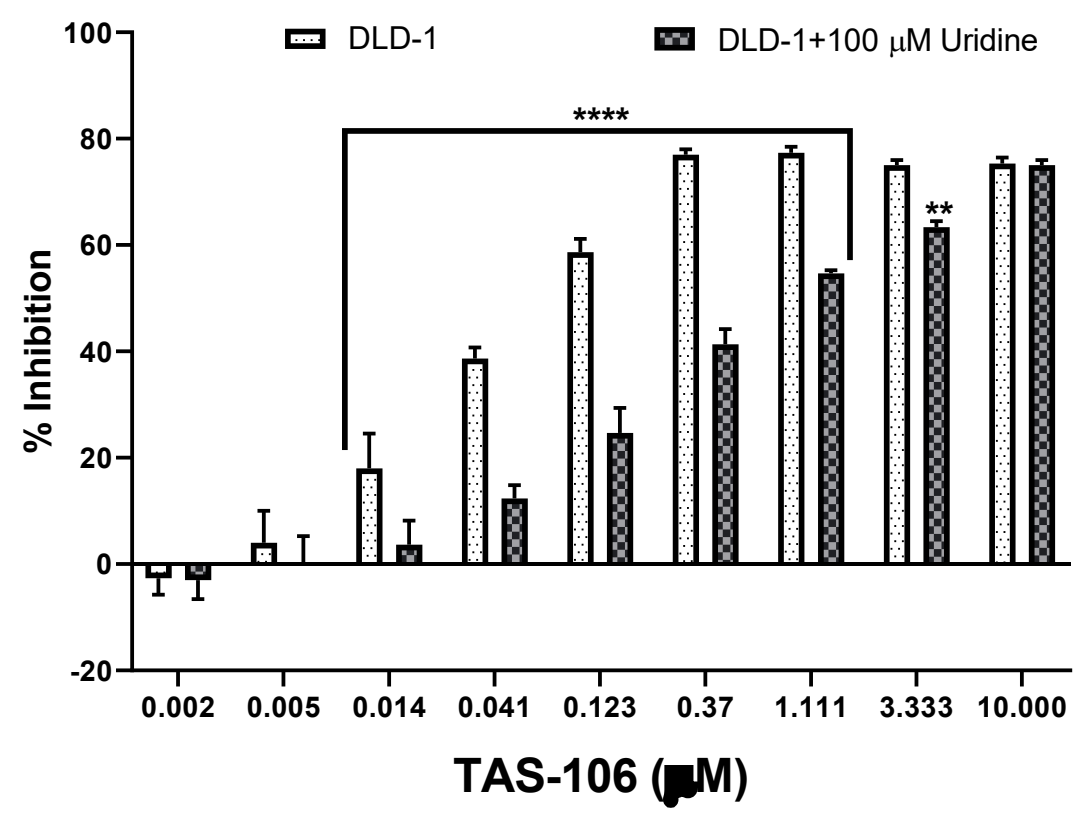

FIGURE 5. Inhibition of DLD-1 cells with TAS-106 and rescue effect with uridine in TAS-106 treated cells. Cells were exposed continuously to the indicated concentrations of TAS-106 inhibitors and $100 \mu \mathrm{M}$ of Urd was added along with TAS-106 for $72 \mathrm{~h}$. Points are the mean \pm SD from three experiments. The significant difference between DLD-1/NC and DLD- $1 /$ siUCK 2 cells was determined using two ways ANOVA. ${ }^{* *} \mathrm{p}<0.01, * * * * \mathrm{p}<0.00001$ were achieved by comparing the TAS-106 treated DLD-1 cells against TAS-106 and Urd supplemented DLD-1 cells 
TABLE 2. EC $_{50}$ of TAS-106 in DLD-1 cells with and without co-administration of uridine

\begin{tabular}{cc}
\hline Treatments & $\mathrm{EC}_{50}(\mu \mathrm{M})$ \\
\hline TAS-106 & 0.036 \\
TAS-106 $+100 \mu \mathrm{M}$ Uridine & 0.330
\end{tabular}

a)

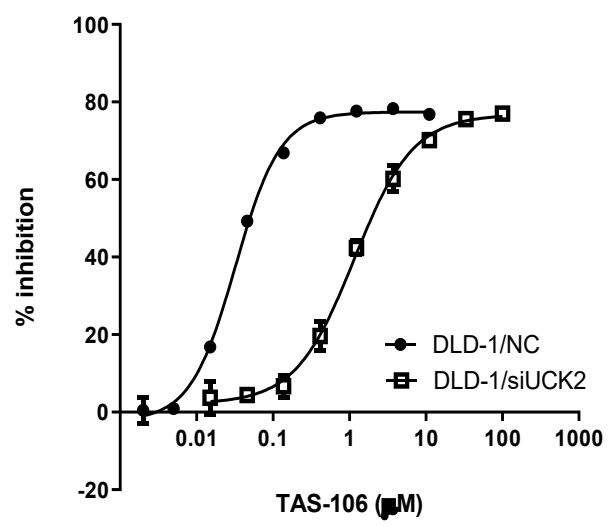

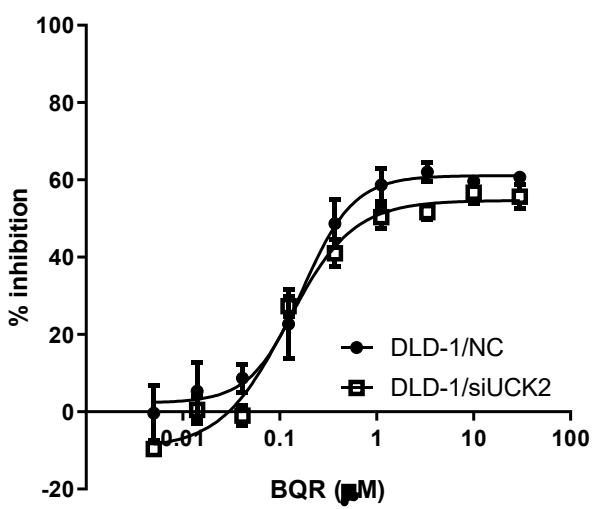

$+100 \mu \mathrm{M}$ Uridine

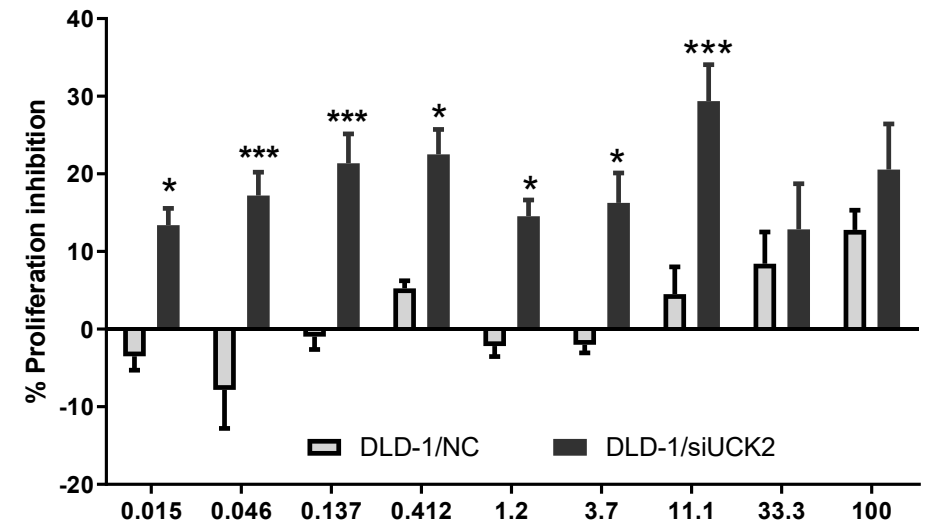

FIGURE 6. Proliferation inhibition of UCK2-knockdown DLD-1 cells treated with TAS-106 or BQR and impact of uridine supplementation a) UCK2 knocked-down DLD-1 cells were treated with TAS106 and BQR, followed by XTT assay post-72 $\mathrm{h}$ treatment. Treatment with TAS-106 is to quantify that the knockdown was successful and maintained throughout the assay performed, b) Both the knockdown cells as well as the negative control cells were seeded and treated with BQR and supplemented with Uridine, followed by XTT assay post- $72 \mathrm{~h}$ treatment. The significant difference between DLD-1/NC and DLD-1/siUCK2 cells was determined using two ways ANOVA. * $\mathrm{p}<0.05$,

$* * \mathrm{p}<0.01, * * * \mathrm{p}<0.001$ were achieved by the DLD-1/siUCK2 cells against DLD-1/NC cells 


\section{DISCUSSION}

Over the last few decades, colorectal cancer (CRC) remains a challenging disease despite multiple advances in medical discovery. Among many common malignant neoplasms in human; colorectal cancer showed one of the highest incidence worldwide with it being the second most common cancer in males and the third most common cancer in females in Malaysia (Ferlay et al. 2010; Siegel et al. 2017; Veettil et al. 2017). A number of drugs namely bevacizumab, aflibercept, regorafenib, cetuximab, and panitumumab targeting various molecular subtypes of colorectal such as methylation of DNA and micro-RNA biogenesis of cancer have been approved by the U.S. Food and Drug Administration (FDA) (Geng et al. 2017; Yiu \& Yiu 2016).

The importance of the pyrimidine synthesis pathway to cancer cells to meet their high demand in DNA and RNA materials has been discussed in our previous reports (Fairus et al. 2020, 2017). The rate-limiting UCK enzyme activity in salvage pathway is important to catalyze the phosphorylation of uridine and nucleosides analogues such as TAS-106 (Murata et al. 2004). Therefore, the level of $U C K 2$ activity is crucial for the effect of TAS-106 at cellular level. It was reported earlier that out of two known $U C K$ isoenzymes, UCK1 and $U C K 2$, the $U C K 2$ isozyme is responsible for the phosphorylation of TAS-106 (Murata et al. 2004). Although many tumours express both $U C K 1$ and $U C K 2$, the expression of $U C K 2$ but not $U C K 1$ was shown to be enhanced in human cancer cells compared to normal cells (Davidsson et al. 2007; Kuilenburg \& Meinsma 2016; Murata et al. 2004). The catalysing capability of UCK2 in uridine and cytosine phosphorylation efficacy is 15-20 times higher than that of UCK1 (Yu et al. 2019). Additionally, UCK1 is also known to be ubiquitously expressed in a variety of normal human tissues, such as skeletal muscle, heart, liver, and kidney, while UCK 2 is only detected in normal human placenta and testis (Yu et al. 2019). Together, these facts led us to prioritize $U C K 2$ over $U C K 1$ for this study.

In this study, a panel of cancer cells from different tissues showed sensitivity to TAS-106 with proliferation inhibition in nanomolar range of $\mathrm{EC}_{50}$. In addition, knockdown of UCK2 was successfully achieved by more than $90 \%$ in DLD-1 and HEK-293 cells compared to negative control cells. Accordingly, siRNA-mediated gene knockdown technique is regarded as one of the widely used tool for in vitro gene function study and it is best that the siRNA used in the experimental model has potent gene-silencing activity (Dorsett \& Tuschl 2004; Hong et al. 2014). Generally, a 50\% knockdown of with siRNA was considered acceptable, $70 \%$ knockdown is good and ideally $>80 \%$ knockdown is expected. Hence, the $90 \%$ knockdown achieved in this study are considered ideal and showed the gene-silencing potency of this siRNA. Nonetheless, upon knockdown, no improvement in $\mathrm{BQR}$ inhibition was observed as shown by the doseresponse curve. Earlier study has reported that DLD-1 cells under normal conditions can survive using salvage pathway even in the presence of the DHODH inhibitors (Miyazaki et al. 2018). They have strongly suggested that the potential to target DHODH in cancer cells living under tumor microenvironment as the cells become highly dependent on the pyrimidine de novo pathways and are also hypersensitive to DHODH inhibitors due to limited supply of pyrimidine precursors used for salvage pathway. We assume that even though we have generated a very good and stable knockdown of $U C K 2$, the potential of hyper-sensitizing the cell to BQR was not able to be accomplished due to the presence of low level UCK2 activity. This is because our TAS-106 treatment in the knockdown cells only showed shift in the $\mathrm{EC}_{50}$ value of TAS-106 by 20 -fold which exhibited there could be some availability of UCK2 to phosphorylate TAS-106 but at a lower potency. As DLD-1 cells is a colorectal cancer cells which is known to grow under tumor microenvironment, the inhibitory effect of $\mathrm{BQR}$ with UCK2 knockdown may have a greater impact in clinical settings. Further studies on the effect of $\mathrm{BQR}$ in in vitro UCK2 knockdown DLD-1 cells under hypoxia condition may reveal the full dependency of this cell on de novo pyrimidine.

Previous studies have reported the protective effect exerted by uridine against drug-induced cytotoxicity in a dose dependent manner (Le et al. 2013; Setzer et al. 2008; Walker et al. 2006). Therefore, supplementation with exogenous uridine recovers the cellular function by replenishing intracellular pyrimidine pools through the salvage pathway (Walker et al. 2006). When this salvage pathway is compromised, the ability of the cells to recover the pyrimidine pool even with exogenous uridine supplementation could be abrogated.

Furthermore, as both Urd and TAS-106 required UCK2 for the phosphorylation, we observed that there was a significant reduction in cell proliferation inhibition when the cells were treated with TAS-106. This showed that TAS-106 and uridine could be competing for phosphorylation by UCK2 enzyme with 10-fold shift in the $\mathrm{EC}_{50}$ of TAS-106. Previous study has suggested 
that when DLD-1 cells was measured by using Urd or TAS-106 as the substrate on UCK2 enzyme activity, Urd phosphorylation activity was approximately 2 fold to TAS-106 phosphorylation activity. The TAS-106 phosphorylation activity in DLD-1 cells was $4.77 \mathrm{nmol} /$ $\mathrm{min} / \mathrm{mg}$ proteins whereas Urd phosphorylation activity was $10.147 \mathrm{nmol} / \mathrm{min} / \mathrm{mg}$ proteins (Shimamoto et al. 2002b). In this study, we observed that when the cells were co-administered with uridine post-knockdown, uridine reversal effect was abrogated in a dose-dependent manner at lesser than $10 \mu \mathrm{M}$ of $\mathrm{BQR}$. Thus, this could be due to the higher preference of the $U C K 2$ enzyme to phosphorylate Urd than TAS-106. Our results on incomplete uridine reversal beyond $10 \mu \mathrm{M}$ of $\mathrm{BQR}$ concentrations was in accordance with previous study in murine colon tumour lines showing that uridine could only reverse the effects of $\mathrm{BQR}$ at concentrations below $30 \mu \mathrm{M}$ (Peters et al. 1992). There are not many reports on the availability of UCK2 inhibitor, but Okesli-Armlovich et al. (2019) have recently screened more than 40000 compounds library in order to study on UCK2 inhibitors. They have narrowed down two potential compounds with a micro-molar range that could inhibit the activity of UCK2 directly. In their preliminary experiments, they have shown that inhibition of DHODH increases uridine salvage which can be suppressed by the UCK2 inhibitor. As mentioned earlier, the availability of $U C K 2$ activity as shown in our TAS-106 inhibitory proliferation assay, maybe sufficient to reverse the inhibition by BQR. Therefore, this shows the potential of targeting both pathways and understanding the dynamic between them could be critical for the use in clinical settings.

With the recent breadth of technology to evaluate synthetic lethality, new combinations with DHODH inhibitors may be uncovered. Cells with mutant PTEN, KRAS and BRAF (V600E) have shown a better sensitivity against DHODH inhibitors (Zeng \& Konopleva 2018). Thus, more studies targeting pyrimidine biosynthesis with DHODH inhibitors in solid tumors are emerging especially via the exploitation of specific genomic backgrounds of the cancer cells. All of these can be obtained, if a thorough research in the whole mechanism of DHODH inhibition is uncovered in cancer cells.

\section{CONCLUSION}

In conclusion, this study demonstrated that UCK2 knockdown does not further sensitize cells towards inhibition of the de novo pathway by BQR. Nevertheless, more studies are needed to truly understand the mechanism involved in de novo pyrimidine inhibition without the UCK2 activity to salvage the pyrimidine in the cells. Studies like protein-protein interactions and molecular docking may be taken in future to evaluate other aspects that could potentially shed some lights in regards of pyrimidine pathways inhibition in cancer cells. On the other hand, significant reduction in uridine rescue showed that the cells ability to convert exogenous uridine to UMP was compromised and we are optimistic that targeting both DHODH and UCK2 in cancer cells are worth exploring. Thus, this may raise more opportunities for studies that use DHODH inhibitors in combination with uridine supplementation to reverse the antiproliferative effect on rapidly dividing normal cells without compromising the impact on cancerous cells.

\section{ACKNOWLEDGEMENTS}

The work was supported by Aurigene Discovery Technologies (M) Sdn. Bhd. The research materials were utilized/procured with the company's fund and the University of Malaya grant Account Number: RP027D15AFR and PG038-2014A. The authors are also thankful to Industrial Doctoral Program sponsorship by the Ministry of Higher Education. KN, MFAK and SO designed the study. MFAK conducted the experiments, data analysis and drafted the manuscript. All authors read and approved the final manuscript. The authors declare that they have no competing interests.

\section{REFERENCES}

Abdelrahim, M., Matsuda, A. \& Naing, A. 2013. TAS-106: Preclinical, clinical and beyond. Oncology 85(6): 356-363.

Balague, C., Pont, M., Prats, N. \& Godessart, N. 2012. Profiling of dihydroorotate dehydrogenase, p38 and JAK inhibitors in the rat adjuvant-induced arthritis model: A translational study. Br. J. Pharmacol. 166(4): 1320-1332.

Baumgartner, R., Walloschek, M., Kralik, M., Gotschlich, A., Tasler, S., Mies, J. \& Leban, J. 2006. Dual binding mode of a novel series of DHODH inhibitors. J. Med. Chem. 49(4): 1239-1247.

Breedveld, F.C. \& Dayer, J.M. 2000. Leflunomide: Mode of action in the treatment of rheumatoid arthritis. Ann. Rheum. Dis. 59(11): 841-849.

Davidsson, J., Andersson, A., Paulsson, K., Heidenblad, M., Isaksson, M., Borg, A., Heldrup, J., Behrendtz, M., Panagopoulos, I., Fioretos, T. \& Johansson, B. 2007. Tiling resolution array comparative genomic hybridization, expression and methylation analyses of $\operatorname{dup}(1 \mathrm{q})$ in Burkitt lymphomas and pediatric high hyperdiploid acute lymphoblastic leukemias reveal clustered near-centromeric breakpoints and overexpression of genes in 1q22-32.3. Hum. Mol. Genet 16(18): 2215-2225. 
Dorasamy, M.S., Choudhary, B., Nellore, K., Subramanya, H. \& Wong, P.F. 2017. Dihydroorotate dehydrogenase inhibitors target c-myc and arrest melanoma, myeloma and lymphoma cells at S-phase. J. Cancer 8(15): 3086-3098.

Dorsett, Y. \& Tuschl, T. 2004. siRNAs: Applications in functional genomics and potential as therapeutics. Nat. Rev. Drug Discov. 3(4): 318-329.

Fairus, A.K.M., Othman, S. \& Nellore, K. 2020. Dihydroorotate dehydrogenase inhibitors promote cell cycle arrest and disrupt mitochondria bioenergetics in ramos cells. Curr. Pharm. Biotechnol. 21(12): 1654-1665.

Fairus, A.K.M., Choudhary, B., Hosahalli, S., Kavitha, N. \& Shatrah, O. 2017. Dihydroorotate dehydrogenase (DHODH) inhibitors affect ATP depletion, endogenous ROS and mediate S-phase arrest in breast cancer cells. Biochimie 135: 154-163.

Ferlay, J., Shin, H.R., Bray, F., Forman, D., Mathers, C. \& Parkin, D.M. 2010. Estimates of worldwide burden of cancer in 2008: GLOBOCAN 2008. Int. J. Cancer 127(12): 28932917.

Galmarini, C.M., Mackey, J.R. \& Dumontet, C. 2001. Nucleoside analogues: Mechanisms of drug resistance and reversal strategies. Leukemia 15(6): 875-890.

Gattermann, N., Dadak, M., Hofhaus, G., Wulfert, M., Berneburg, M., Loeffler, M.L. \& Simmonds, H.A. 2004. Severe impairment of nucleotide synthesis through inhibition of mitochondrial respiration. Nucleos. Nucleot. Nucl. 23(8-9): 1275-1279.

Geng, F., Wang, Z., Yin, H., Yu, J. \& Cao, B. 2017. Molecular targeted drugs and treatment of colorectal cancer: Recent progress and future perspectives. Cancer Biother. Radiopharm. 32(5): 149-160.

Hoffmann, H.H., Kunz, A., Simon, V.A., Palese, P. \& Shaw, M.L. 2011. Broad-spectrum antiviral that interferes with de novo pyrimidine biosynthesis. Proc. Natl. Acad. Sci. 108(14): 5777-5782.

Hong, S.W., Jiang, Y., Kim, S., Li, C. \& Lee, D.K. 2014. Target gene abundance contributes to the efficiency of siRNAmediated gene silencing. Nucleic Acid Ther. 24(3): 192198.

Katahira, R. \& Ashihara, H. 2002. Profiles of pyrimidine biosynthesis, salvage and degradation in disks of potato (Solanum tuberosum L.) tubers. Planta 215(5): 821-828.

Kazuno, H., Shimamoto, Y., Tsujimoto, H., Fukushima, M., Matsuda, A. \& Sasaki, T. 2007. Mechanism of action of a new antitumor ribonucleoside, 1-(3-C-ethynyl-beta-D-ribopentofuranosyl)cytosine (ECyd, TAS-106), differs from that of 5-fluorouracil. Oncol. Rep. 17(6): 1453-1460.

Kuilenburg, A.B.P.V. \& Meinsma, R. 2016. The pivotal role of uridine-cytidine kinases in pyrimidine metabolism and activation of cytotoxic nucleoside analogues in neuroblastoma. Biochim. Biophysic. Acta (BBA) - Mol. Basis of Dis. 1862(9): 1504-1512.

Le, T.T., Ziemba, A., Urasaki, Y., Hayes, E., Brotman, S. \& Pizzorno, G. 2013. Disruption of uridine homeostasis links liver pyrimidine metabolism to lipid accumulation. J. Lipid Res. 54(4): 1044-1057.
Lolli, M.L., Sainas, S., Pippione, A.C., Giorgis, M., Boschi, D. \& Dosio, F. 2018. Use of human dihydroorotate dehydrogenase (hDHODH) inhibitors in autoimmune diseases and new perspectives in cancer therapy. Recent Pat. Anticancer Drug Discov. 13(1): 86-105.

Matsuda, A. \& Sasaki, T. 2004. Antitumor activity of sugarmodified cytosine nucleosides. Cancer Sci. 95(2): 105-111.

Matsuda, A., Fukushima, M., Wataya, Y. \& Sasaki, T. 1999. A new antitumor nucleoside, 1-(3-C-ethynyl-beta-D-ribopentofuranosyl)cytosine (ECyd), is a potent inhibitor of RNA synthesis. Nucleos Nucleot 18(4-5): 811-814.

Miyazaki, Y., Inaoka, D.K., Shiba, T., Saimoto, H., Sakura, T., Amalia, E., Kido, Y., Sakai, C., Nakamura, M., Moore, A.L., Harada, S. \& Kita, K. 2018. Selective cytotoxicity of dihydroorotate dehydrogenase inhibitors to human cancer cells under hypoxia and nutrient-deprived conditions. Front. Pharmacol. https://doi.org/10.3389/ fphar.2018.00997.

Murata, D., Endo, Y., Obata, T., Sakamoto, K., Syouji, Y., Kadohira, M., Matsuda, A. \& Sasaki, T. 2004. A crucial role of uridine/cytidine kinase 2 in antitumor activity of 3'-ethynyl nucleosides. Drug Metab. Dispos. 32(10): 11781182.

Naito, T., Yokogawa, T., Kim, H.S., Futagami, M., Wataya, Y., Matsuda, A., Fukushima, M., Kitade, Y. \& Sasaki, T. 2002. Anticancer mechanisms of 1-(3-C-ethynyl-beta-D-ribopentofuranosyl) cytosine (ECyd, TAS-106). Nucleic Acids Res. Suppl. 2: 241-242.

Okesli-Armlovich, A., Gupta, A., Jimenez, M., Auld, D., Liu, Q., Bassik, M.C. \& Khosla, C. 2019. Discovery of small molecule inhibitors of human uridine-cytidine kinase 2 by high-throughput screening. Bioorganic Med. Chem. Lett. 29(18): 2559-2564

Okesli, A., Khosla, C. \& Bassik, M.C. 2017. Human pyrimidine nucleotide biosynthesis as a target for antiviral chemotherapy. Curr. Opin. Biotechnol. 48: 127-134.

Ortiz-Riaño, E., Ngo, N., Devito, S., Eggink, D., Munger, J., Shaw, M.L., Torre, J.C.D.L. \& Martínez-Sobrido, L. 2014. Inhibition of arenavirus by A3, a pyrimidine biosynthesis inhibitor. J. Virol. 88(2): 878-889.

Peters, G.J., Kraal, I. \& Pinedo, H.M. 1992. In vitro and in vivo studies on the combination of Brequinar sodium (DUP-785; NSC 368390) with 5-fluorouracil; effects of uridine. Br. J. Cancer 65(2): 229-233.

Sarkisjan, D., Julsing, J.R., Smid, K., Klerk, D.D., Kuilenburg, A.B.P.V., Meinsma, R., Lee, Y.B., Kim, D.J. \& Peters, G.J. 2016. The cytidine analog fluorocyclopentenylcytosine (RX-3117) is activated by Uridine-Cytidine Kinase 2. PLoS ONE 11(9): e0162901.

Schröder, M., Giermann, N. \& Zrenner, R. 2005. Functional analysis of the pyrimidine de novo synthesis pathway in solanaceous species. Plant Physiol. 138(4): 1926-1938.

Setzer, B., Lebrecht, D. \& Walker, U.A. 2008. Pyrimidine nucleoside depletion sensitizes to the mitochondrial hepatotoxicity of the reverse transcriptase inhibitor stavudine. Am. J. Pathol. 172(3): 681-690. 
Shimamoto, Y., Kazuno, H., Murakami, Y., Azuma, A., Koizumi, K., Matsuda, A., Sasaki, T. \& Fukushima, M. 2002a. Cellular and biochemical mechanisms of the resistance of human cancer cells to a new anticancer ribo-nucleoside, TAS- 106 . Jpn. J. Cancer Res. 93(4): 445-452.

Shimamoto, Y., Koizumi, K., Okabe, H., Kazuno, H., Murakami, Y., Nakagawa, F., Matsuda, A., Sasaki, T. \& Fukushima, M. 2002b. Sensitivity of human cancer cells to the new anticancer ribo-nucleoside TAS-106 is correlated with expression of Uridine-cytidine Kinase 2. Jpn. J. Cancer Res. 93(7): 825-833.

Siegel, R.L., Miller, K.D., Fedewa, S.A., Ahnen, D.J., Meester, R.G.S., Barzi, A. \& Jemal, A. 2017. Colorectal cancer statistics, 2017. CA. Cancer J. Clin. 67(3): 177-193.

Sykes, D.B., Kfoury, Y.S., Mercier, F.E., Wawer, M.J., Law, J.M., Haynes, M.K., Lewis, T.A., Schajnovitz, A., Jain, E., Lee, D., Meyer, H., Pierce, K.A., Tolliday, N.J., Waller, A., Ferrara, S.J., Eheim, A.L., Stoeckigt, D., Maxcy, K.L., Cobert, J.M., Bachand, J., Szekely, B.A., Mukherjee, S., Sklar, L.A., Kotz, J.D., Clish, C.B., Sadreyev, R.I., Clemons, P.A., Janzer, A., Schreiber, S.L. \& Scadden, D.T. 2016. Inhibition of dihydroorotate dehydrogenase overcomes differentiation blockade in acute myeloid leukemia. Cell 167(1): 171-186. e15.

Veettil, S.K., Lim, K.G., Chaiyakunapruk, N., Ching, S.M. \& Hassan, M.R.A. 2017. Colorectal cancer in Malaysia: Its burden and implications for a multiethnic country. Asian $J$. Surg. 40(6): 481-489.

Walker, U.A., Auclair, M., Lebrecht, D., Kornprobst, M., Capeau, J. \& Caron, M. 2006. Uridine abrogates the adverse effects of antiretroviral pyrimidine analogues on adipose cell functions. Antivir. Ther. 11(1): 25-34.

Wang, Q.Y., Bushell, S., Qing, M., Xu, H.Y., Bonavia, A., Nunes, S., Zhou, J., Poh, M.K., Sessions, P.F.D., Niyomrattanakit, P., Dong, H., Hoffmaster, K., Goh, A., Nilar, S., Schul, W., Jones, S., Kramer, L., Compton, T. \& Shi, P.Y. 2011. Inhibition of dengue virus through suppression of host pyrimidine biosynthesis. J. Virol. 85(13): 6548-6556.
Yiu, A.J. \& Yiu, C.Y. 2016. Biomarkers in colorectal cancer. Anticancer Res. 36(3): 1093-1102.

Yu, S., Li, X., Guo, X., Zhang, H., Qin, R. \& Wang, M. 2019. UCK2 upregulation might serve as an indicator of unfavorable prognosis of hepatocellular carcinoma. IUBMB Life 71(1): 105-112.

Zeng, Z. \& Konopleva, M. 2018. Targeting dihydroorotate dehydrogenase in acute myeloid leukemia. Haematologica 103(9): 1415-1417.

Mohamad Fairus Abdul Kadir

Aurigene Discovery Technologies (M) Sdn. Bhd.

Level 2, Research Management and Innovation Complex

University of Malaya

50603 Kuala Lumpur, Federal Territory

Malaysia

Mohamad Fairus Abdul Kadir, Puteri Shafinaz Abdul-Rahman \& Shatrah Othman*

Department of Molecular Medicine

Faculty of Medicine

University of Malaya

50603 Kuala Lumpur, Federal Territory

Malaysia

Kavitha Nellore

Aurigene Discovery Technologies Limited

39-40, KIADB Industrial Area

Electronic City Phase II, Hosur Road

Bangalore 560100 Karnataka

India

*Corresponding author; email: shatraho@um.edu.my

Received: 22 October 2019

Accepted: 17 November 2020 